\title{
DISSERTAÇÕES E TESES
}

Título

Ilumina-Ação: Diálogos entre a Gestalt-terapia e o Zen-Budismo

Autor(a) Roberto Peres Veras

Instituição Pontifícia Universidade Católica de São Paulo

Programa Mestrado em Psicologia Clínica

Banca $\quad$ Marília Ancona Lopez E Grisi (Orientadora)

Gilberto Safra (PUC-SP)

Luiz Lilienthal (Instituto de Gestalt de São Paulo)

Defesa $\quad 26$ de Outubro de 2005.

Resumo Este trabalho teve como objetivo, por meio da análise de conceitos da Gestalt-terapia e do ZenBudismo, estabelecer um diálogo entre esses dois universos tendo em vista contribuir para o desenvolvimento do corpo teórico da Gestalt-terapia. Como método de investigação utilizou-se o modelo gestáltico através do processo de formação e destruição de figuras (gestalten). Inicialmente delineou-se o ponto de partida ou figura inicial, o interesse de Perls, principal expoente da Gestalt-terapia, pelo Zen-Budismo. A leitura e análise de suas obras e de sua autobiografia permitiu delinear seu contato com o Zen-Budismo e conseqüentemente sua reverberação na criação da Gestalt-terapia. No corpo teórico da Gestalt-terapia, alguns conceitos estão relacionados ao Zen-Budismo e outros revelam uma grande aproximação, como o fluxo de awareness ou continuum de awareness e a meditação. As concepções de homem da Gestalt-terapia e do Zen-Budismo foram investigadas, assim como os conceitos de self, "eu", o "aqui e agora", e a temporalidade assinalando-se suas convergências e divergências. Vinhetas advindas da prática da clínica da Gestalt-terapia, historietas e mondos do Zen-Budismo contribuíram para a compreensão dos conceitos desenvolvidos no presente trabalho. O diálogo estabelecido permitiu identificar os principais eixos de articulação entre a Gestalt-terapia e o Zen-Budismo assim como as diferenças fundamentais que distinguem suas identidades.

Palavras-chave ～Palavras-chave: Zen-Budismo; Awareness; Iluminação; Gestalt-terapia.

Abstract The main purpose of this study is to establish the relationship between Gestalt-therapy and ZenBuddhism universes, based on a conceptual analysis for contributing to Gestalt-therapy theoretical development. Gestalt model has been adopted as investigation methodology using the creation and destruction figures (gestalten). Initially it was determined Perls as the start up reference or initial figure, due to his interest in Zen-Buddhism. The analysis of his collected works and auto-biography has defined his contact with Buddhism and, as consequence, its reverberation in Gestalt-therapy creation. Within Gestalt-therapy theoretical content, some concepts are related to Zen and others illustrate a close interaction, as the awareness flow/continuum awareness and meditation. Both Gestalt-therapy and Zen-Buddhism have been investigated on the human being conceptual analysis perspective, as well as "self", 'I', 'here and now', temporality, addressing their similarities and differences. Situations captured from Gestalt-Therapy clinical practice, stories and Zen-Buddhism 'mondos' have contributed for the understanding of concepts presented in this study. This relationship establishment has allowed the identification of main articulation structures between Gestalttherapy and Zen-Buddhism, pointing out the fundamental topics that differentiate their identities

Keywords Zen- Buddhism; Awareness; Gestalt-therapy. 